\title{
Organization Science
}

Articles in Advance, pp. 1-18

ISSN 1047-7039 (print) | ISSN 1526-5455 (online)

http://dx.doi.org/10.1287/orsc. 1120.0788

(C) 2012 INFORMS

\section{Corporate Structure and Performance Feedback: Aspirations and Adaptation in M-Form Firms}

\author{
Vibha Gaba \\ INSEAD, Singapore 138676, vibha.gaba@insead.edu \\ John Joseph \\ Fuqua School of Business, Duke University, Durham, North Carolina 27708, john.e.joseph@duke.edu
}

\begin{abstract}
Tn this study, we examine how business units of multidivisional (M-form) firms adapt their activities in response to poor performance at the corporate and business unit levels. By linking performance feedback theory with theories of attention and $\mathrm{M}$-form organizations, we show that corporate structure influences the relationship between performance below aspirations and business unit adaptation. Because corporate structure vertically differentiates performance goals and problemistic search, solutions to performance problems vary across corporate and business unit levels, with divergent implications for business unit adaptation. We examine business unit adaptation empirically through new product introductions in the global mobile device industry, finding that poor performance at the business unit level leads to greater new product introductions. In contrast, corporate-level responses to performance problems have a negative cross-level effect on new product introductions. We also find that these negative effects are attenuated for strategically significant business units, which have more input into corporate responses. By linking structural and behavioral drivers of action, this paper contributes to the knowledge and understanding of adaptive behavior in multidivisional firms.
\end{abstract}

Key words: adaptation; performance feedback; multiple goals; M-form organization

History: Published online in Articles in Advance.

\section{Introduction}

A large body of research suggests that low performance motivates firms to alter their internal activities and to seek new products, markets, and strategies (Audia and Brion 2007, Greve 2007, Park 2007, Iyer and Miller 2008, Vissa et al. 2010, Gaba and Bhattacharya 2012). Yet in the multidivisional (M-form) firm, which features corporate allocation of resources and business units that focus on implementation and operations (Chandler 1962, Williamson 1975), adaptive behavior depends on corporate and business unit responsibilities, goals, and performance (Galunic and Eisenhardt 2001). In particular, poor performance at different levels of the firm may not have uniform consequences for the behavior of business unit managers, a central driver of adaptive change (Bower 1970, Burgelman 1991). Our goal in this paper is to understand these differences and to examine the effects of corporate and business unit performance below aspirations on business unit adaptation - specifically, on unit efforts to launch new products.

Performance feedback has long been recognized as an important mechanism for adaptive behavior (Cyert and March 1963), and it is based on the premise that firms learn from experience and alter activities conditional on their performance below an aspiration level or reference point (Greve 2003b). Performance feedback models are fairly robust, but most assume that all organizational units either share the same aspiration level (e.g., Bromily 1991, Greve 1998) or adopt the aspiration level of top management (e.g., Lant et al. 1992, Miller and Chen 1994, Audia et al. 2000). The empirical research's focus on singular aspiration levels has supplanted the Carnegie School's original notion of multiple goals (Simon 1947, March and Simon 1958, Cyert and March 1963) and has hindered theoretical treatment of adaptive behavior amidst multiple performance goals.

Studies have recently begun to examine the adaptive implications of different functional goals. The separation of functional activities allows functional areas to operate semiautonomously-allowing, for example, marketing to deal with product sales and operations to deal with supply chain management. As a result, efforts to correct unsatisfactory performance reflect the interests and aspiration levels of the focal subunit. For example, Baum et al. (2005) find that marketing- and investment-related aspirations have independent effects on a bank's selection of investment partners. Similarly, Audia and Sorenson (2001) argue that the division of labor between business and technology managers in computer manufacturing firms leads to differences in their aspirations. Functional subunits create and monitor their own unique performance metrics and react differently to environmental feedback. 
Although these studies provide useful insights into the behavioral outcomes that follow from horizontally differentiated goals, researchers have yet to consider the role that corporate goals and hierarchy play in business unit adaptation through performance feedback. This is a crucial oversight because corporate-level responses to poor performance may have different adaptive implications for business units than do those units' own responses. A business unit's response to poor performance will likely target its own operations and product market activities with limited impact on other parts of the organization (Simon 1962). However, the corporate office is concerned about the overall enterprise, so its responses to unsatisfactory performance may have crosslevel effects on adaptive behavior of constituent business units. In particular, we ask the following two questions: How does corporate structure affect a firm's responses to poor performance? What are the effects of corporate and business unit performance below aspirations on business unit behavior?

We empirically examine the effects of performance below aspirations, at both corporate and business unit levels, on business unit adaptation using quarterly data on mobile device manufacturers for the period 2002-2008. This single-industry setting, which is dominated by global multibusiness firms, provides an opportunity to examine the effects of performance feedback across multiple levels of organizational hierarchy. We focus on performance below aspirations because it activates problem-driven search rather than planned or institutional search, for which behavioral interpretations of adaptation may be less central (Greve 2003b). For our dependent variable-adaptive behavior of the business unit-we measure the rate of product introductions. New product introductions are a critical activity for unit adaptation and survival (Dougherty 1992, Brown and Eisenhardt 1995). This is especially true in hightech industries, where new products facilitate the transformation of firms and the industries in which they are embedded (Burgelman 1991).

Our primary thesis is that problemistic search differs as a function not only of corporate versus business unit performance problems but also of the respective level's responses. We argue that, because performance shortfalls at the business unit level activate responses that focus on revenue enhancements and efficiency improvements, the rate of new product introductions increases. In contrast, poor performance at the corporate level may lead to reductions in discretionary spending and to disruptive reorganizations at the firm level, which constrain business unit managers and reduce the rate of new product introductions. In addition, when corporate performance declines, the business units may become more cautious and limit changes because they anticipate a tightening of resources and control. We posit that the corporatelevel effects are attenuated for strategically significant business units, which have disproportionate weight in decision making and are less concerned about declines in corporate performance. Such business units may be granted more discretion by the corporate office and so may be able to limit corporate actions that would otherwise hinder new product introductions.

This paper makes two main contributions. First, we show the behavioral outcomes of attention to multiple goals within a vertical hierarchy. We link performance feedback theory (Greve 2003b) to theories of attention (Ocasio 1997, Bouquet and Birkinshaw 2008, Joseph and Ocasio 2012) and M-form organizations (Chandler 1962, Williamson 1975) in order to explain how adaptive behavior through performance feedback is realized in the multidivisional firm. This consideration of the corporate structure and multiple goals addresses a limitation of existing research on performance feedback, which relies heavily on the assumption that aspirations and reactions to poor performance are uniform throughout the firm. Second, by linking structural and behavioral mechanisms in a decision-making model of adaptive change, our study provides a better understanding of cross-level effects - in particular, of the corporate level on business unit responses to poor performance. Our work extends foundational M-form studies as well as more recent work on adaptation in multibusiness firms, which typically do not integrate behavioral mechanisms. We also extend the behavioral theory of the firm, which ignores the implications of corporate structure for problemistic search in complex organizations.

\section{Problemistic Search in the Multidivisional Firm}

A core idea in the behavioral theory of the firm is that decision makers refer to an aspiration level, which is "the smallest outcome that would be deemed satisfactory by the decision maker" (Schneider 1992, p. 1053), when evaluating performance. Decision making with reference to aspiration levels is the result of boundedly rational decision makers attempting to simplify evaluation by transforming a continuous measure of performance into a discrete measure of success or failure (Greve 2003b). Failure to achieve aspirations is said to trigger problemistic search-in other words, "search that is stimulated by a problem... and is directed toward finding a solution to that problem" (Cyert and March 1963, p. 121). In practical terms, the solutions sought by managers are drawn from response repertoires designed to close the performance-aspiration gap. Response repertoires are similar to what Miller and Chen $(1994,1996)$ call "competitive" repertoires and are the strategic and tactical levers available to managers for dealing with performance problems. These repertoires of actions will vary in their comprehensiveness and intensity depending on the cause and extent of the performance shortfall (Hambrick and D'Aveni 1988). 
An overlooked consideration in the literature is that problemistic search following poor performance (and the solutions found) are likely to differ across levels in a multidivisional firm. The multidivisional firm was designed, in part, to deal with bounded rationality and by limits on the amount of information that decision makers can process (Simon 1957, Chandler 1962, Williamson 1985). Multibusiness firms are characterized by a decentralized system of semiautonomous operating units and a corporate office with responsibility for overall firm performance, strategy, and the allocation of resources among divisions. The corporate structure allocates the attention of corporate executives and business unit managers to firmwide and business unit performance goals, respectively (Ocasio 1995). As a result, the relevance of discrepancies between aspirations and current performance will vary with the structural position of decision makers within the corporate hierarchy. Also differing will be the respective responses to poor performance, given that the underlying assumptions of problemistic search have different implications at the corporate versus business unit level of decision making.

According to the behavioral theory of the firm, there are three underlying assumptions of problemistic search: (1) problem solving is motivated in areas considered important by managers and their key constituents, (2) problem solving is shaped by managers' experiences and by the information available to them for decision making, and (3) problem solutions are sought "near" the symptoms. These basic assumptions do not exhaust the possibilities for contextual elements activating distinct corporate and business unit responses to performance problems. However, they do cover the key theoretical considerations highlighted in the foundational theory (Cyert and March 1963) and are also critical to the problem-solving activities of organizations.

First, corporate and business unit managers have different motivations because of their different goals and corresponding pressures from their respective constituents. Business units are under pressure from the corporate office to achieve unit-specific performance targets. At the business unit level, these parochial aspirations (e.g., unit profitability) set the evaluative standard that activates problemistic search when performance is unsatisfactory (Audia and Sorenson 2001). At the corporate level, however, attention to firm-level performance reflects external pressures to achieve quarterly earnings (profit) goals. Corporate executives, including the chief executive officer (CEO), are subject to pressure from such firm constituents as financial analysts and investors (Kaplan and Minton 2006, Wiersema and Zhang 2011). Profit goals are reinforced by social, cultural, and economic incentives that, in turn, drive short-term behavior.

Second, corporate and business unit managers bring different biases to problem-solving efforts, biases that are shaped by each manager's background and experience. Whereas business unit managers are anchored by their experiences in the industry and the local product market in which they operate, corporate executives are relatively distant from the routine operation of business units and are more concerned about the overall enterprise's strategy and performance (Chandler 1962, p. 309). Hence the corporate office's problem-solving activities derive from portfolio management experience, not from the product market experience of their business unit counterparts. Moreover, these biases shape the nature of information sought to ground decisions, which in turn reinforces the distinct responses of corporate and business unit managers.

Third, causal models of decision making differ across levels. At the business unit level, parochial goals and divisional autonomy make for relatively close links among problem symptoms, causes, and solutions. That focus helps business unit managers more accurately diagnose problems and converge on appropriate solutions to those problems (Ethiraj and Levinthal 2004). However, causal models at the corporate level are more complex. This is because corporate decision makers typically face many interdependent problems that must be managed simultaneously. As a result, these managers seek broad solutions that cover a range of different problems across the corporation's entire portfolio of businesses.

In short, responses of the corporate office and business units to performance problems differ significantly, which suggests that these responses have distinctive implications for business unit behavior. In the next section we develop hypotheses regarding how the different response repertoires available to the corporate versus the business unit level affect the latter's adaptive behavior in the form of new product introductions.

\section{Effects of Corporate and Business Unit Performance Feedback}

\section{Business Unit Response Repertoires and New Product Introductions}

The assumptions underlying problemistic search at the business unit level suggest that business unit managers react to poor performance of their unit with initiatives that target internal operations and core products. These responses are driven by corporate pressures on the business unit to achieve satisfactory levels of performance. In multidivisional firms, corporate executives allocate cash flow to promising business units and establish internal incentives and controls to monitor resources (Williamson 1985). Unit managers must demonstrate satisfactory performance so that the corporate office will continue to provide the funds necessary to finance growth and pursue opportunities. For this reason, business unit responses designed to address unsatisfactory 
performance reflect managerial attempts to increase the size and prominence of their respective operating divisions and to compete with other units for resources on the basis of differential profit performance (Williamson 1970). When performance is poor, solutions that would affect other business units are less favored than solutions that target the focal unit's product market. Facing poor performance, business unit managers are also likely to eschew investing in products with long development cycles in favor of a focus on solutions that accelerate new product introductions.

This parochial focus is reinforced by the experience and knowledge of business unit decision makers. Because the responsibility for operating decisions is assigned to subunits (Williamson 1970, 1975), the expertise of their managers is grounded in the unit's industry and product markets. Industry experience reinforces prevailing models of how the industry operates, and it also aids managers in identifying a set of rivals (Porac and Thomas 1990) and directing new product commercialization (Tripsas and Gavetti 2000). A parochial focus affects what information is sought and how it is interpreted (Daft and Weick 1984) - in particular, the information on products, technologies, and markets that are relevant to the focal business unit. As a result, the experience of business unit managers is likely to restrict the search for solutions to internal operations and focal product markets.

Operational solutions include improving efficiency, reducing costs, and increasing output (Hambrick and Schecter 1983). Business unit managers may attempt to rationalize manufacturing, improve support systems, and limit the number of approvals required in the development process (Krubasik 1988). Product market solutions will likely target core products. To increase revenue, the business unit may shift human capital from exploratory or long-term projects to more current projects that are closer to shipping. Hence less attention is given to uncertain technologies, markets, or products for which the unit has limited capabilities (Hambrick and Schecter 1983). For example, when a performance downturn hit Motorola in 2006, managers were pulled off internal ventures targeted for commercialization in 3-5 years and reassigned to teams whose products were targeted to launch within the next quarter. As one vice president at Motorola noted in a phone interview following the downturn, "Motorola has to do what it has to do to be profitable. If you are not building a device, you are just doing something that helps a device get shipped." Therefore our first hypothesis is as follows.

HyPOTHESIS 1 (H1). As the business unit performanceaspiration gap (below aspirations) increases, the rate of new product introductions increases.

\section{Corporate Response Repertoires and New Product Introductions}

Poor performance at the corporate level also shapes new product introductions, the consequence of corporate response repertoires. Corporate response repertoires are, in part, affected by the pressures of external constituents, such as the investment community. Research has demonstrated that analyst and investor concerns about a firm's earnings and stock price induce corporate managers to behave myopically (Stein 1989). Myopic investment behavior refers to the deliberate underinvestment in long-term products in order to meet short-term goals (Porter 1992). Thus executives seek to pump up earnings and thereby raise forecasted value, because higher shortterm earnings will be viewed as an indicator of higher future earnings (Stein 1989). The investment community rewards firms that exhibit such myopic behavior. Research has shown, for example, that analysts are more attentive and positive toward incumbent strategies that extend and preserve an existing technology than toward strategies that incorporate products with new technologies (Benner 2010).

Myopic investment may be manifest in a corporate emphasis on short-term performance and the elimination of spending that lacks a clear relationship with short-term profitability (Cyert and March 1963, p. 171). When performance problems arise, corporate managers may cut discretionary spending (e.g., advertising, travel, training) and human resources (e.g., by laying off consultants or even employees) in an attempt to increase current earnings and focus the business units on core activities (Bushee 1998). The downside to such resource tightening is its negative effect on the firm's front line, where such spending can help with the development and launching of new products. Business unit managers are left with fewer resources to distribute and are forced to reduce investments in new programs. Even if resource tightening does not occur immediately, a downturn in corporate performance may signal impending reductions and thus impel business unit managers to cut back on a variety of activities.

Corporate managers also come to rely on broad costcutting measures because tactical solutions are more difficult to devise. The M-form organization is a multilevel decision-making environment (Bower 1970) that creates complexity in the assessment of performance solutions. Although corporate managers can recognize declines in profitability, they know less than frontline managers about optimal solutions. Rather, corporate managers, who typically lack firsthand knowledge about the specifics of the industry, technological area, or geographic region in which they operate (Hill and Hoskisson 1987), are more well versed in portfolio management. Absent a detailed operational understanding of specific businesses, corporate managers may prefer to mandate a 
tightening of resources and simply let the business unit managers determine where to make the cuts.

Corporate managers also rely more heavily than do unit managers on such objective evaluation criteria as financial information, which by its nature is removed from operational activities (Hoskisson et al. 1993) and reflects more generic performance indicators that can nonetheless activate perceptions of success and failure. A related aspect of firm-level feedback is that it may uncover a host of problems that should all be addressed. Thus, a corporate-level problemistic search process may involve more organizational resources and lead to responses that could solve multiple problems. For example, another mechanism relied on by corporate managers to improve performance is changing the organizational structure (Haveman 1992). Reorganizations, consolidations, and divestitures are all common responses to a performance downturn, especially because such reorganization is often designed to solve multiple problems. However, the resulting changes are extremely disruptive to business unit activities (Miller and Friesen 1984) and may therefore impede the units' efforts to improve performance-specifically, by affecting new product introductions.

In summary, the effects of cross-level responses on business unit behavior may discourage adaptive change through new products. This is because corporate managers, in responding to corporate performance declines, may take actions that constrain business unit managers (e.g., by cutting costs in ways that curtail unit-level actions or issuing directives that limit new initiatives). At the same time, corporate performance declines may lead business unit managers to be more cautious because they anticipate a tightening of resources and control; whether or not they materialize, the expectations themselves discourage managers from making changes. So rather than an increase in new product introductions, as suggested in the literature (e.g., Greve 2003b), corporate performance declines may actually result in a decrease.

As one manager in the mobile devices business unit at Motorola noted, in his response to corporate cuts: "If we jump forward to the hemorrhaging that is going on right now... I had to lay off a huge part of my team here. But I think we are making short-term decisions at the expense of the long-term. I think we are throwing the baby out with the bathwater. I know why they are making [those decisions]. Motorola has to do what they have to do to be profitable." We are thus led to suggest our next hypothesis.

HYPOTHESIS 2 (H2). As the corporate performanceaspiration gap (below aspirations) increases, the rate of new product introductions decreases.

\section{Variation in Corporate Attention to Business Units}

Our arguments so far have isolated the effects of corporate and business unit performance feedback. We have argued that performance declines at the business unit level activate response repertoires that lead to more new product introductions, whereas corporate responses to poor performance have the opposite effect. Now we consider conditions under which business unit behavior is less affected by corporate responses to poor performance. We posit that greater corporate attention to a particular business unit may influence corporate priorities and investments in favor of that unit and thus improve its capacity to adapt. Business units capable of garnering greater corporate attention are those that are strategically significant, which lends them a greater voice and weight in corporate decision making and problem solving (Bouquet and Birkinshaw 2008). Strategically significant business units include those that account for a large share of the firm's financial performance and those with experience in providing solutions to the firm. These are important contingencies because strategically significant business units affect the corporate agenda (Joseph and Ocasio 2012).

The greater the business unit's contribution to corporate income, the greater the scrutiny that unit will likely receive from such key external constituents as financial analysts and investors. Under these conditions, the corporate office may be more sensitive to the potential negative effects stemming from its responses to poor performance on the business unit's ability to adapt. The corporate office may accordingly be less inclined to cut resources, so business unit managers of strategically significant units may be less concerned about the threat of loss.

Greater contribution to overall firm performance is also likely to provide these business unit managers with access to key positions within the firm. One possible consequence is reduced information asymmetry between the corporate office and business units regarding product market information and performance feedback. Unit managers will interact more frequently with corporate executives and exert more influence in upperechelon decision making (Pfeffer 1992), which would make unilateral corporate-level actions less probable or altogether unnecessary. Instead, corporate managers may come to accept product market-related solutions more readily than broader financial or structural solutions. When many of the firm's key positions are held by unit managers, corporate responses are less likely to impede business unit activities, or alternatively, business unit solutions will substitute for corporate solutions. In either case, the result is a reduction in the adverse effects of corporate performance feedback on business unit behavior. Formally, we propose the following hypothesis. 
HYPOTHESIS 3 (H3). Corporate-level performance feedback effects on new product introductions are attenuated for business units that generate a significant share of corporate income.

Business units with a great deal of experience may also be considered strategically significant and so have greater influence on corporate decision making (Bouquet and Birkinshaw 2008). Extensive experience in the product market increases a business unit's problem-solving capacity and its ability to manage environmental contingencies effectively (Hickson et al. 1971). Research suggests that subsidiary initiatives (e.g., new products or services) that could increase overall firm value are the most likely to draw favorable attention from corporate headquarters. Hence a unit that has already produced many successful products may be given an increased contributory role (Birkinshaw et al. 1998) and thus greater involvement in corporate learning and responses to feedback. In other words, business units with more experience have more influence at the corporate leveland this includes "selling" corporate managers on their solutions. With respect to new proposals, organizations tend to favor those developed in high-influence parts of the organization (Burgelman and Grove 1996); this in turn should reduce the adverse effects on new product introductions that typically follow corporate responses to poor performance. With experience, business units gain the confidence of corporate managers, have more freedom to enact change, and can guard against resource decrements. Thus we have our final hypothesis, as follows.

НYротнеSIS 4 (H4). Corporate-level performance feedback effects on new product introductions are attenuated for business units that have more extensive experience.

\section{Methods}

\section{Sample}

Our sample consists of six firms in the global mobile device industry: Nokia, Motorola, Samsung, Sony Ericsson, Siemens, and LG. These firms are the largest cellular phone manufacturers in the world and accounted for $70 \%-85 \%$ of total unit sales during the period of our study. The global mobile device industry is an ideal setting in which to examine the effects of corporate and business unit performance feedback on new product introductions. First, the major players in the industry are all multidivisional firms, which allows us to operationalize variables at both the corporate and business unit levels and then to examine differential responses to performance feedback at each level. Second, this industry features a high rate of new product introductions. That allows us to use quarterly data, in which there is sufficient variation over time-in both our dependent and independent variables - to enable identification of our hypothesized effects. That the data are quarterly also allows us to analyze relatively shorter performance feedback loops of business units and longer feedback loops of the corporate office. Third, product strategies for the firms in our sample are roughly similar and focus on a wide variety of mobile phones. We collected quarterly data from the first quarter of 2002 through the last quarter in 2008. In compiling these data, we relied on Internet searches as well as the World Cellular Information Service, the Informa World Cellular Handset Tracker, and the Strategy Analytics SpecTRAX database of mobile phones.

\section{Measures}

Dependent Variable. Our dependent variable is new product introductions as measured by the number of new phones introduced during each quarter in a year. Firms in the mobile phone industry operate in a dynamic competitive environment characterized by short product life cycles; thus handset manufacturers are required to deliver a continuous stream of new products. In such an environment, continuous adaptation through high rates of new product introductions is crucial. We follow Martin and Mitchell (1998) and Katila and Ahuja (2002) in defining a new product as a change in design characteristics. A mobile phone qualifies as "new" if at least one of its design characteristics differs from those of the firm's previous products.

Independent Variables. Because we aim to examine the differences in corporate and business unit responses to performance shortfalls, our performance variables must be comparable across these levels of organizational hierarchy. Prior literature on performance feedback (e.g., Greve 2003b, Miller and Chen 2004, Audia and Greve 2006) commonly uses return on assets (ROA) to measure corporate performance. These studies do not focus on the $\mathrm{M}$-form structure and seldom make distinctions between corporate and business unit performance, so ROA suffices to capture performance at the corporate level. Yet there is no business unit-level analogue to ROA because few firms provide accounting data on assets at the subunit level. However, our interviews and examination of analyst reports on Motorola and its internal company memos all suggest that operating profit margins are carefully monitored by managers at both the corporate and business unit levels. For example, a 2007 internal memo from the CEO to the firm following its performance downturn read as follows: "The shortfall in both sales and earnings occurred in our Mobile Devices business. ... What are we doing about it? Puting together a comprehensive plan to improve our operating profitability." In another internal memo, the CEO emphasized that Motorola "won't chase market share for the sake of market share at the expense of margins and profits." Given 
this focus on profit margins at both the corporate and business unit levels, our performance measure is operating profit margin, defined by the ratio of operating income to sales. For the corporate unit, this means corporate operating income as a fraction of corporate sales; for the business unit, it means business unit operating income as a fraction of business unit sales.

Aspiration Levels. Following previous studies (Greve 2003a, Audia and Greve 2006), we calculate the historical aspirations of firm $i$ as an exponentially weighted moving average of its past performance. Let $H A_{i t}^{u}$ denote the historical aspirations of firm $i$ at time $t$, where $u$ indexes corporate versus business unit performance. Then $H A_{i t}^{u}=\alpha P_{i t-1}^{u}+(1-\alpha) H A_{i t-1}^{u}$, where $P_{i t}^{u}$ is the performance in terms of operating profit margin of the $i$ th firm at level $u$ and $\alpha$ is an adjustment parameter. The weight $\alpha$ was chosen by searching over all possible values in increments of 0.1 and then using the value that yielded the maximum log-likelihood. This procedure resulted in $\alpha=0.1$ (respectively, $\alpha=0.3$ ) for the corporate (respectively, business unit) measure.

Following Cyert and March (1963) and Greve (2003a), we also computed aspiration levels as a weighted average of social and historical aspirations: $A_{i t}^{u}=\beta S A_{i t-1}^{u}+(1-\beta) H A_{i t-1}^{u}$. Here, $S A_{i t}^{u}$, firm $i$ 's social aspiration at the $u$ th level $(u=$ corporate or business unit) at time $t$, is the simple average of the appropriate performance variable over every other firm. That is, $S A_{i t}^{u}=\sum_{j \neq i}\left(P_{j t}^{u} / N\right)$, where $P_{j t}^{u}$ is the $j$ th's firm performance and $N=5$ is the total number of other firms in firm $i$ 's industry sector.

We use Clarke's (2003) distribution-free test to pick the weights of social and historical aspirations. The test is based on the ratio of individual log-likelihoods from a pair of nonnested models and provides a hypothesis test for selecting one of those two models. At the corporate level, the Clarke test selects the model that puts all the weight on historical aspirations; at the business unit level, it also selects a model that puts all the weight on historical aspiration-but only at the $10 \%$ level of significance. At the 5\% level, the test is unable to select between a model that puts $100 \%$ weight on historical aspirations and the best-fitting model that puts $60 \%$ weight on historical aspirations and $40 \%$ weight on social aspirations. At the same time, chi-square tests fail to reject that the hypothesis that coefficients in the two models are significantly different. So as to better align comparisons across levels of corporate hierarchy, we therefore use only historical aspirations in all our models. Finally, in a post hoc analysis, we show that the Bayesian information criterion selects the model with only historical aspirations over the model that uses both social and historical aspirations.
Performance-Aspiration Gap. This gap is defined as the difference between the performance and aspiration levels for each of the corporate and business units. We implemented a spline function to compare the effects of the performance-aspiration gap above and below the aspiration level (Greve 2003a) by splitting each performance variable into two variables. Performance below aspirations equals 0 for all observations in which the performance (at the corporate or business unit level) of the focal firm is greater than its aspirations; for all other observations, it equals the difference between the performance and aspirations. Performance above aspirations is defined symmetrically: it is 0 when the performance is below the aspirations and equals the performanceaspiration gap when performance falls above the aspirations. The gap variables in the empirical specification are lagged by one quarter for the business unit and by four quarters for the corporate unit; these lags were chosen on the basis of model maximum likelihood and the distribution-free test of Clarke (2003). Our qualitative observations of new product introductions in the mobile device industry also support this choice of lags. ${ }^{1}$

To examine the role of business unit strategic significance, we use variables that capture two characteristics of the unit. First, $B U$ importance is measured as the ratio of business unit operating income to the firm's overall operating income of the firm, and it captures the relative importance of the business unit in corporate performance. Second, $B U$ experience is measured as the cumulative number of prior mobile phones introduced by the business unit; this variable reflects the relative experience of the business unit. To test $\mathrm{H} 3$ and $\mathrm{H} 4$, we interact each of these variables with the performance-aspiration gap of the corporation unit. ${ }^{2}$

Control Variables. To isolate the impact of theorized variables on new product introductions, we control for several other factors when estimating the model. First, we control for a variety of firm-level characteristics. As firms age, they acquire both experience in introducing new products (Sorenson and Stuart 2000) and inertia that may impede quick response (Abernathy and Utterback 1978). To control for age, we count the years since a firm's founding. Because firms with a large stock of resources have the financial and human resources to overcome performance problems (Mitchell 1994), we also control for firm size. For this, we use two variables: the number of employees and the value of corporate sales, both of which are logged. We include firm diversification as a control because greater diversification is reflected in corporate structure and may affect responsiveness to performance feedback at both the corporate and business unit level. Firm diversification is calculated using the entropy measure (Palepu 1985), which is the weighted average of the log of inverse sales for each unit of the firm. We also include a control 
for the number of mobile patents for which the focal firm has applied, as patents often translate directly into new phone introductions. Patent data were drawn from Thompson Innovation and include worldwide patents for mobile device technology. Excess organizational resources (slack) enable firms to experiment and change (Cyert and March 1963, Greve 2003b). We use two measures of slack: available slack as measured by the firm's current ratio (the ratio of current assets to liabilities) and absorbed slack as measured by the ratio of sales, general, and administrative expenses to sales. The former variable captures the liquid resources that are uncommitted to liabilities (Bromily 1991), and the latter represents resources already absorbed by certain operational activities yet still recoverable if necessary. ${ }^{3}$

All our specifications are demanding in that they include both firm-specific and quarter-year dummies. Thus we rely on within-firm variations over time to identify the hypothesized effects. The firm dummies account for all time-invariant, firm-specific unobserved heterogeneity; the time dummies account for common global and industry time effects (e.g., density of firms and mobile products, global growth in demand). In addition, if new product introductions are subject to seasonal factors, then the quarter-year dummies should also account for these effects. ${ }^{4}$

Table 1 provides summary statistics as well as correlations between the predictor variables. ${ }^{5}$

\section{Model Specification}

New product introductions is a count variable that takes integer values from 0 onward with the data censored at zero. Either a Poisson or a negative binomial model specification is appropriate when the dependent variable is a count measure. The mean value for new product introductions is 20.26 and the variance is 239.3. A variance that is, as here, nearly 12 times the mean indicates overdispersion, so a negative binomial model that explicitly estimates an overdispersion parameter may seem more appropriate than a Poisson model, which assumes equality of mean and variance. However, it is important to distinguish between true overdispersion and merely apparent overdispersion (Cameron and Trivedi 2005). Apparent overdispersion may arise when relevant variables are omitted. After incorporating firm and time fixed effects into the Poisson model, we find that standard tests for overdispersion (Hardin and Hilbe 2007, Cameron and Trivedi 2005) fail to reject the null of overdispersion. Hence the data are only apparently overdispersed, as there is no evidence for overdispersion once we incorporate a comprehensive set of firm and time fixed effects.

Incorporating multiple fixed-effect vectors into an unconditional negative binomial specification is problematic. It leads to an incidental parameters problem and inconsistent estimates, a problem not encountered with the Poisson model. Dropping the fixed-effect vectors is not a solution either because the omission of relevant variables biases the estimates (Hausman et al. 1984). The negative binomial conditional fixed-effects model does not have an incidental parameter problem. However, as Allison and Waterman (2002) highlight, it builds the fixed effects into the distribution of the overdispersion parameter, not the mean. ${ }^{6}$ For the Poisson model, the conditional and unconditional fixed-effect estimates coincide; it is not subject to the incidental

Table 1 Summary Statistics and Cross-Correlations $(N=152)$

\begin{tabular}{|c|c|c|c|c|c|c|c|c|c|c|c|c|c|c|c|}
\hline \multirow[b]{2}{*}{ Variables } & \multirow[b]{2}{*}{ Mean } & \multirow[b]{2}{*}{ S.D. } & \multicolumn{13}{|c|}{ Variables } \\
\hline & & & 1 & 2 & 3 & 4 & 5 & 6 & 7 & 8 & 9 & 10 & 11 & 12 & 13 \\
\hline 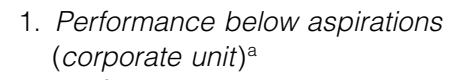 & -0.02 & 0.03 & 1 & & & & & & & & & & & & \\
\hline $\begin{array}{l}\text { 2. Performance above aspirations } \\
(\text { corporate unit })^{\mathrm{a}}\end{array}$ & 0.03 & 0.05 & 0.34 & 1 & & & & & & & & & & & \\
\hline $\begin{array}{l}\text { 3. Performance below aspirations } \\
\text { (business unit) }\end{array}$ & -0.01 & 0.03 & 0.1 & 0.12 & 1 & & & & & & & & & & \\
\hline 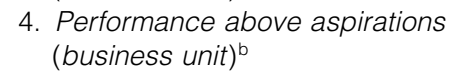 & 0.03 & 0.06 & -0.02 & -0.06 & 0.26 & 1 & & & & & & & & & \\
\hline 5. $A g e^{C}$ & 4.41 & 0.52 & 0.12 & 0.15 & 0.13 & 0.14 & 1 & & & & & & & & \\
\hline 6. Number of employees ${ }^{c}$ & 4.3 & 0.66 & 0.04 & -0.01 & 0.15 & 0.00 & 0.29 & 1 & & & & & & & \\
\hline 7. Corporate sales ${ }^{\mathrm{C}}$ & 9.07 & 0.52 & -0.04 & -0.14 & 0.01 & -0.28 & 0.05 & 0.75 & 1 & & & & & & \\
\hline 8. Diversification ${ }^{c}$ & 0.09 & 0.46 & 0.04 & -0.32 & -0.04 & -0.25 & -0.38 & 0.48 & 0.5 & 1 & & & & & \\
\hline 9. Mobile patents ${ }^{\mathrm{C}}$ & 6.78 & 1.4 & -0.06 & -0.22 & -0.12 & -0.67 & -0.38 & 0.17 & 0.56 & 0.56 & 1 & & & & \\
\hline 10. Available slack ${ }^{c}$ & 2.3 & 1.09 & -0.14 & -0.01 & -0.05 & -0.18 & -0.6 & 0.08 & 0.38 & 0.16 & 0.4 & 1 & & & \\
\hline 11. Absorbed slack ${ }^{\mathrm{C}}$ & 7.57 & 0.49 & -0.04 & -0.1 & 0.01 & -0.09 & 0.38 & 0.83 & 0.87 & 0.32 & 0.21 & 0.11 & 1 & & \\
\hline 12. $B U$ importance & 0.33 & 1.01 & 0.15 & -0.01 & 0.38 & 0.02 & 0.09 & -0.04 & 0.05 & -0.08 & 0.07 & 0.05 & -0.04 & 1 & \\
\hline 13. $B \cup$ experience $e^{b, c}$ & 5.05 & 1.14 & -0.13 & -0.08 & -0.26 & -0.51 & -0.47 & -0.07 & 0.25 & 0.18 & 0.63 & 0.44 & 0.01 & -0.08 & 1 \\
\hline
\end{tabular}

aLagged by four quarters.

'Lagged by one quarter.

cIn natural logs. 
parameters problem and does not exhibit small-sample bias or underestimate the standard errors (Greene 2003). Wooldridge (1999) shows that the fixed-effects Poisson estimator produces consistent estimates of the parameters in a multiplicative, unobserved components panel data model under very general conditions and is robust to serial correlation. ${ }^{7}$ Therefore, we use a Poisson fixedeffects specification and correct for overdispersion by scaling the model standard errors by the deviance-based dispersion statistic (Cameron and Trivedi 2005, Hardin and Hilbe 2007).

\section{Results}

Table 2 shows the fixed-effects Poisson models for the number of new phones introduced each quarter. Model 1 includes only the control variables, whereas Models 2-4 add the performance-aspiration gap variables for the corporate and business units. Model 2 includes only the performance variables relevant for the business unit, Model 3 includes only the corporate performance variables, and Model 4 includes performance variables for both the corporate and business unit levels.

In Model 1 we find that older firms are relatively inert and less likely to introduce new phone models. Size as measured by number of employees (but not corporate sales) has a positive effect on new product introductions, whereas diversification seems to have no influence. Although the number of mobile patents seems not to matter for new phone introductions in Model 1, in subsequent models we find that firms with more patents also have a higher rate of new product introductions. ${ }^{8}$ The variables available slack, $B U$ importance, and $B U$ experience have no direct effect on new product introductions. The lack of significant results for these measures reflects our inclusion of firm-specific fixed effects. If we omit those firm dummies, then the coefficient for available slack is both positive and significant, as is the coefficient for $B U$ importance. Absorbed slack has a negative and significant sign in Model 1, a finding similar to Greve (2003a), who finds that a negative sign for absorbed slack impacts innovation launches in the presence of firm fixed effects. Finally, a likelihood ratio test shows that Model 1 as a whole is significant at the $1 \%$ level.

Model 2 examines the effect of the performanceaspiration gap above and below the firm's aspiration level, where performance is measured in terms of operating profit margins at the business unit level. According to Hypothesis 1, business unit performance below aspirations leads to a greater number of new product introductions. We obtain a negative and significant coefficient for performance below aspirations, supporting H1. In other words, as performance deteriorates and the business unit's operating profit margins move farther away from its aspiration level, the unit increases the rate at which it introduces new products. In contrast, performance above aspirations for the business unit does not seem to affect the number of new product introductions. Using a likelihood ratio test to compare Models 1 and 2, we obtain a chi-square test statistic (with 2 degrees of freedom) of 8.42 ; this yields a $p$-value of 0.01 , which suggests that including the performance-aspiration gap measures is responsible for a substantial improvement in model fit.

Table 2 Fixed-Effects Poisson Model of New Phone Introductions

\begin{tabular}{|c|c|c|c|c|}
\hline \multirow[b]{2}{*}{ Variable } & \multicolumn{4}{|c|}{ Model } \\
\hline & 1 & 2 & 3 & 4 \\
\hline $\begin{array}{l}\text { Performance below } \\
\text { aspirations } \\
\text { (business unit) }\end{array}$ & & $\begin{array}{r}-2.682^{*} \\
(1.432)\end{array}$ & & $\begin{array}{r}-2.305^{*} \\
(1.402)\end{array}$ \\
\hline $\begin{array}{l}\text { Performance above } \\
\text { aspirations } \\
\text { (business unit) }\end{array}$ & & $\begin{array}{l}2.256 \\
(1.419)\end{array}$ & & $\begin{array}{l}2.103 \\
(1.374)\end{array}$ \\
\hline $\begin{array}{l}\text { Performance below } \\
\text { aspirations } \\
\text { (corporate unit) }\end{array}$ & & & $\begin{array}{l}3.087^{* *} \\
(1.423)\end{array}$ & $\begin{array}{l}2.916^{* *} \\
(1.412)\end{array}$ \\
\hline $\begin{array}{l}\text { Performance above } \\
\text { aspirations } \\
\text { (corporate unit) }\end{array}$ & & & $\begin{array}{c}-2.074^{* *} \\
(0.978)\end{array}$ & $\begin{array}{c}-1.922^{* *} \\
(0.973)\end{array}$ \\
\hline Age & $\begin{array}{l}-0.013^{* * *} \\
(0.004)\end{array}$ & $\begin{array}{l}-0.012^{* * *} \\
(0.004)\end{array}$ & $\begin{array}{l}-0.011^{* * *} \\
(0.004)\end{array}$ & $\begin{array}{l}-0.010^{* * *} \\
(0.004)\end{array}$ \\
\hline Number of employees & $\begin{array}{l}0.937^{* * *} \\
(0.215)\end{array}$ & $\begin{array}{l}1.033^{* * *} \\
(0.225)\end{array}$ & $\begin{array}{l}1.048^{* * *} \\
(0.213)\end{array}$ & $\begin{array}{l}1.120^{* * *} \\
(0.223)\end{array}$ \\
\hline Corporate sales & $\begin{array}{c}0.187 \\
(0.335)\end{array}$ & $\begin{array}{c}0.265 \\
(0.335)\end{array}$ & $\begin{array}{l}0.016 \\
(0.341)\end{array}$ & $\begin{array}{c}0.084 \\
(0.343)\end{array}$ \\
\hline Diversification & $\begin{array}{c}0.149 \\
(0.159)\end{array}$ & $\begin{array}{c}0.098 \\
(0.159)\end{array}$ & $\begin{array}{c}0.069 \\
(0.159)\end{array}$ & $\begin{array}{c}0.028 \\
(0.158)\end{array}$ \\
\hline Mobile patents & $\begin{array}{c}0.120 \\
(0.089)\end{array}$ & $\begin{array}{r}0.160^{*} \\
(0.095)\end{array}$ & $\begin{array}{r}0.156^{*} \\
(0.086)\end{array}$ & $\begin{array}{l}0.191^{* *} \\
(0.092)\end{array}$ \\
\hline Available slack & $\begin{array}{c}0.066 \\
(0.062)\end{array}$ & $\begin{array}{c}0.086 \\
(0.062)\end{array}$ & $\begin{array}{l}0.030 \\
(0.061)\end{array}$ & $\begin{array}{c}0.049 \\
(0.062)\end{array}$ \\
\hline Absorbed slack & $\begin{array}{r}-0.469^{*} \\
(0.254)\end{array}$ & $\begin{array}{c}-0.595^{* *} \\
(0.258)\end{array}$ & $\begin{array}{c}-0.534^{* *} \\
(0.251)\end{array}$ & $\begin{array}{c}-0.633^{* *} \\
(0.256)\end{array}$ \\
\hline BU importance & $\begin{array}{r}-0.014 \\
(0.018)\end{array}$ & $\begin{array}{r}-0.015 \\
(0.018)\end{array}$ & $\begin{array}{r}-0.018 \\
(0.018)\end{array}$ & $\begin{array}{r}-0.020 \\
(0.018)\end{array}$ \\
\hline BU experience & $\begin{array}{r}-0.343 \\
(0.344)\end{array}$ & $\begin{array}{r}-0.192 \\
(0.347)\end{array}$ & $\begin{array}{r}-0.364 \\
(0.335)\end{array}$ & $\begin{array}{r}-0.221 \\
(0.339)\end{array}$ \\
\hline Constant & $\begin{array}{l}6.402^{* *} \\
(3.259)\end{array}$ & $\begin{array}{l}5.081 \\
(3.269)\end{array}$ & $\begin{array}{l}8.134^{* *} \\
(3.290)\end{array}$ & $\begin{array}{l}6.833^{* *} \\
(3.318)\end{array}$ \\
\hline $\begin{array}{l}\text { Number of } \\
\text { observations }\end{array}$ & 152 & 152 & 152 & 152 \\
\hline $\begin{array}{l}\text { Number of firms } \\
\text { Pseudo log-likelihood }\end{array}$ & $\begin{array}{c}6 \\
-453.55\end{array}$ & $\begin{array}{c}6 \\
-449.34\end{array}$ & $\begin{array}{c}6 \\
-447.21\end{array}$ & $\begin{array}{c}6 \\
-443.88\end{array}$ \\
\hline $\begin{array}{l}\text { Overall model test } \\
\text { [degrees of freedom] }\end{array}$ & $\begin{array}{c}646.70^{* * * *} \\
{[40]}\end{array}$ & $\begin{array}{c}698.32^{* * *} \\
{[41]}\end{array}$ & $\begin{array}{c}669.49^{* * *} \\
{[42]}\end{array}$ & $\begin{array}{c}715.54^{* * *} \\
{[43]}\end{array}$ \\
\hline
\end{tabular}

Notes. Standard errors (in parentheses) are corrected for overdispersion by multiplying them by the square root of the ratio of the goodness-of-fit chi-square value to the number of degrees of freedom. All columns include time (quarter-year) and firm fixed effects. The performance-aspiration gap variables are lagged by four quarters for the corporate unit and by one quarter for the business unit.

*Significant at $10 \%$; ** significant at $5 \%$; ${ }^{* * *}$ significant at $1 \%$. 
Figure 1 New Product Introductions' Multiplier Rate

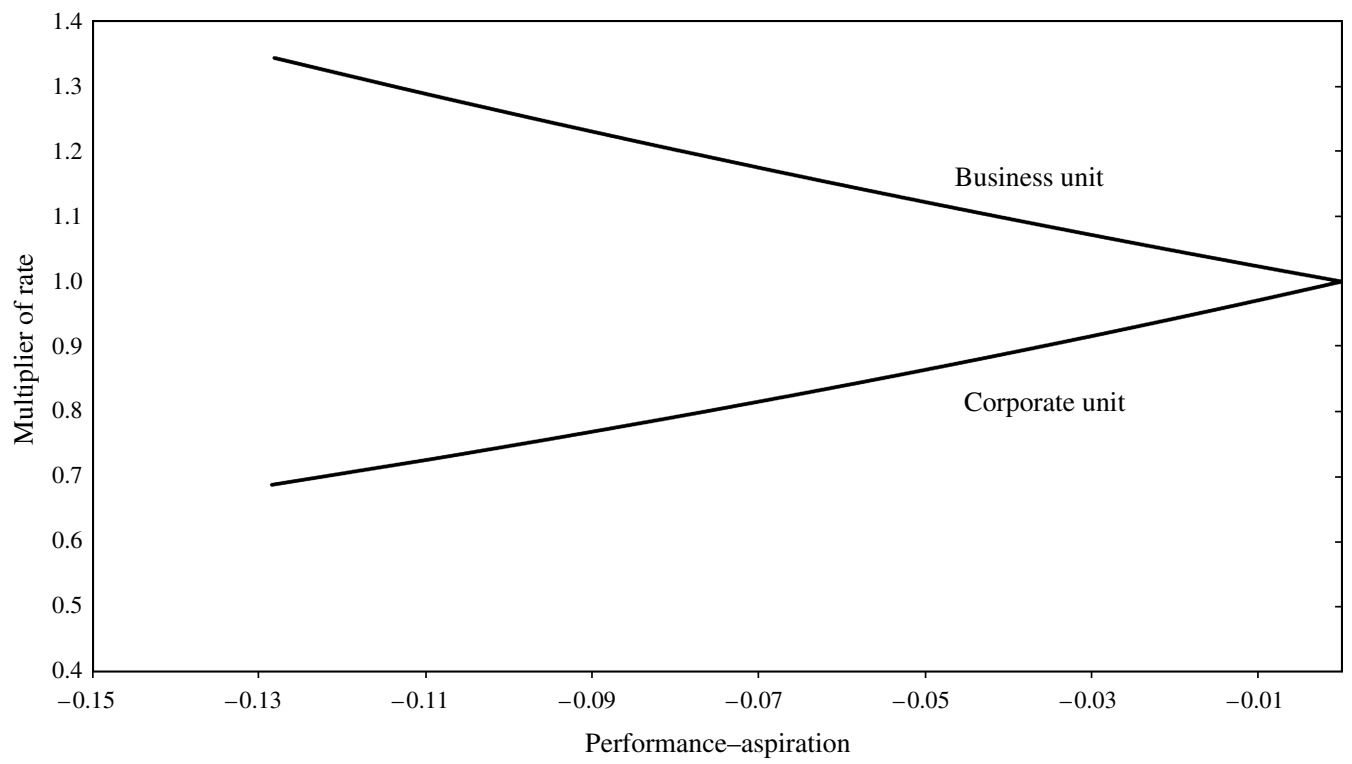

Model 3 adds the two performance-aspiration gap measures for the corporate level to Model 1. Hypothesis 2 predicted that, for corporate performance below aspirations, negative feedback (i.e., performance declines) will lead to fewer new product introductions. The positive and significant coefficient for performance below aspirations supports Hypothesis 2 by indicating that, as performance below aspirations declines, so does the rate of new phone introductions. ${ }^{9}$ We also find that for performance above historical aspirations, performance improvements result in fewer new product introductions. A likelihood ratio test comparing Models 1 and 3 yields a chi-square test statistic of 12.68 (with 2 degrees of freedom and $p=0.001$ ), suggesting a significant improvement in model fit over Model 1.

Model 4 adds the performance-aspiration variables for both corporate and business units. We find that the results from Models 2 and 3 continue to be supported: an increase in the performance-aspiration gap for the business (respectively, corporate) unit increases (respectively, reduces) new product introductions. Comparing Model 4 to Models 2 and 3 yields chi-square test statistics of 6.66 and 10.92, respectively, which are significant at the $5 \%$ and $1 \%$ levels. This suggests that a model that includes performance-aspiration gaps at both the corporate and business unit levels dominates models that include the performance-aspiration gap at only one unit. Overall, our results support the heterogeneity of responses-in terms of new product introductionsto performance-aspiration gaps at multiple levels of the corporate hierarchy.

Model 4 also allows us to calculate the magnitude of the effects of performance-aspiration gaps for the corporate unit versus the business unit. ${ }^{10}$ We calculate the average marginal effects of changes in the performanceaspiration gap below the aspiration level while holding all other variables at their mean levels. The estimates in Model 4 imply that an increase of one standard deviation in the corporate performance-aspiration gap below aspirations reduces the rate of new phone introductions by $6.1 \%$ and that a one-standard-deviation increase in this gap for the business unit increases the rate of new phone introductions by $7.8 \%$. Using the Delta method (Greene 2003) to calculate the standard errors of the average marginal effects (not shown), we find that each effect is significantly different from zero.

Figure 1 plots our results based on the coefficient estimates in Model 4. It shows the multiplier effect of the performance-aspiration gap (below aspirations) on new product introductions for the corporate and business units. To facilitate interpretation, in the figure we set the rate of new product introductions to unity at the origin and vary the gaps over their entire range of values. We find that the corporate curve slopes upward whereas the business curve slopes downward. This result implies that declining performance at the firm level (moving toward the left on the horizontal axis) reduces the rate of product introductions but that declining performance in the business unit increases that rate.

Next, Hypotheses 3 and 4 state that the effect of a corporate performance-aspirations gap on new product introductions is moderated by the relative importance and experience of the business unit. In Table 3, Model 5 interacts the corporate performance-aspiration gap with $B U$ importance while Model 6 interacts that gap with $B U$ experience. In Model 5, the coefficient for the gap remains positive while that on the interaction term is negative. This suggests that, even though declining corporate performance below aspirations reduces the 
Gaba and Joseph: Corporate Structure and Performance Feedback: Aspirations and Adaptation in M-Form Firms

Table 3 Fixed-Effects Poisson Model of New Phone Introductions

\begin{tabular}{|c|c|c|}
\hline \multirow[b]{2}{*}{ Variable } & \multicolumn{2}{|c|}{ Model } \\
\hline & 5 & 6 \\
\hline $\begin{array}{l}\text { Performance below aspirations } \\
\quad \text { (business unit) }\end{array}$ & $\begin{array}{c}-2.132^{* *} \\
(0.920)\end{array}$ & $\begin{array}{c}-2.233^{* *} \\
(1.021)\end{array}$ \\
\hline $\begin{array}{l}\text { Performance above aspirations } \\
\text { (business unit) }\end{array}$ & $\begin{array}{c}2.132 \\
(1.887)\end{array}$ & $\begin{array}{c}2.154 \\
(1.714)\end{array}$ \\
\hline $\begin{array}{l}\text { Performance below aspirations } \\
\text { (corporate unit) }\end{array}$ & $\begin{array}{r}3.044^{*} \\
(1.653)\end{array}$ & $\begin{array}{r}2.920^{*} \\
(1.743)\end{array}$ \\
\hline $\begin{array}{l}\text { Performance above aspirations } \\
\text { (corporate unit) }\end{array}$ & $\begin{array}{l}-1.650^{* * * *} \\
(0.377)\end{array}$ & $\begin{array}{c}-1.931^{* *} \\
(0.803)\end{array}$ \\
\hline $\begin{array}{l}\text { BU importance } \times \text { Performance } \\
\quad \text { below aspirations (corporate unit) }\end{array}$ & $\begin{array}{r}-0.218 \\
(0.190)\end{array}$ & \\
\hline $\begin{array}{l}\text { BU importance } \times \text { Performance } \\
\text { above aspirations (corporate unit) }\end{array}$ & $\begin{array}{r}-0.449 \\
(0.889)\end{array}$ & \\
\hline $\begin{array}{l}\text { BU experience } \times \text { Performance } \\
\quad \text { below aspirations (corporate unit) }\end{array}$ & & $\begin{array}{c}-0.074 \\
(0.162)\end{array}$ \\
\hline $\begin{array}{l}B \cup \text { experience } \times \text { Performance } \\
\text { above aspirations (corporate unit) }\end{array}$ & & $\begin{array}{c}0.010 \\
(0.157)\end{array}$ \\
\hline Age & $\begin{array}{l}-0.010^{* * *} \\
(0.002)\end{array}$ & $\begin{array}{c}-0.010^{* * *} \\
(0.001)\end{array}$ \\
\hline Number of employees & $\begin{array}{l}1.087^{* * *} \\
(0.135)\end{array}$ & $\begin{array}{l}1.106^{* * *} \\
(0.127)\end{array}$ \\
\hline Corporate sales & $\begin{array}{c}0.081 \\
(0.178)\end{array}$ & $\begin{array}{c}0.113 \\
(0.209)\end{array}$ \\
\hline Diversification & $\begin{array}{c}0.034 \\
(0.208)\end{array}$ & $\begin{array}{c}0.033 \\
(0.217)\end{array}$ \\
\hline Mobile patents & $\begin{array}{l}0.188 \\
(0.123)\end{array}$ & $\begin{array}{c}0.193 \\
(0.129)\end{array}$ \\
\hline Available slack & $\begin{array}{r}0.052^{*} \\
(0.031)\end{array}$ & $\begin{array}{c}0.045 \\
(0.028)\end{array}$ \\
\hline Absorbed slack & $\begin{array}{l}-0.625^{* * *} \\
(0.204)\end{array}$ & $\begin{array}{c}-0.656^{* * *} \\
(0.229)\end{array}$ \\
\hline BU importance & $\begin{array}{r}-0.029^{*} \\
(0.015)\end{array}$ & $\begin{array}{c}-0.018^{* *} \\
(0.007)\end{array}$ \\
\hline$B U$ experience & $\begin{array}{r}-0.217 \\
(0.324)\end{array}$ & $\begin{array}{c}-0.214 \\
(0.298)\end{array}$ \\
\hline Constant & $\begin{array}{r}6.821^{*} \\
(3.574)\end{array}$ & $\begin{array}{r}6.666^{*} \\
(3.479)\end{array}$ \\
\hline Number of observations & 152 & 152 \\
\hline Number of firms & 6 & 6 \\
\hline Log-likelihood & -443.63 & -443.80 \\
\hline $\begin{array}{l}\text { Overall model test } \\
\text { (degrees of freedom) }\end{array}$ & $\begin{array}{c}704.91^{* * *} \\
(46)\end{array}$ & $\begin{array}{c}701.99^{* * *} \\
(46)\end{array}$ \\
\hline
\end{tabular}

Note. See notes to Table 2.

*Significant at $10 \% ;{ }^{* *}$ significant at $5 \% ;{ }^{* * *}$ significant at $1 \%$.

number of new products introduced, this effect is attenuated for the more important business units. Model 6 reveals a similar effect. Performance below aspirations at the corporate level again makes new product introductions less likely, but in this case the effect is attenuated for the more experienced business units. The coefficients for the stand-alone term (business unit share of operating income in Model 5 and business unit experience in Model 6) are not significant in either of the two models. ${ }^{11}$
Table 4 Marginal Effects of Performance Below Aspirations (Corporate Unit) on New Product Introductions by Level of Business Unit Importance and Experience

\begin{tabular}{lcc}
\hline $\begin{array}{l}\text { Range of } \\
\text { moderating } \\
\text { variable }\end{array}$ & $\begin{array}{c}(1) \\
\text { Moderating variable: } \\
\text { BU importance }\end{array}$ & $\begin{array}{c}(2) \\
\text { Moderating variable: } \\
\text { BU experience }\end{array}$ \\
\hline Mean - 3 S.D. & $4.352^{* * *}$ & $6.737^{* * *}$ \\
Mean - 2 S.D. & $(1.346)$ & $(2.242)$ \\
& $3.916^{* * *}$ & $5.731^{* * *}$ \\
Mean - 1 S.D. & $(1.352)$ & $(1.827)$ \\
& $3.48^{* *}$ & $4.726^{* * *}$ \\
Mean & $(1.461)$ & $(1.483)$ \\
& $3.044^{*}$ & $3.721^{* * *}$ \\
Mean + 1 S.D. & $(1.653)$ & $(1.268)$ \\
& 2.608 & $2.715^{* *}$ \\
Mean + 2 S.D. & $(1.902)$ & $(1.251)$ \\
& 2.172 & 1.710 \\
Mean + 3 S.D. & $(2.189)$ & $(1.439)$ \\
& 1.736 & 0.704 \\
& $(2.502)$ & $(1.767)$ \\
\hline
\end{tabular}

Notes. Standard errors (in parentheses) are calculated using the Delta method. The marginal effects for $B U$ importance (share of corporate income generated) are based on estimates in Model 5; marginal effects for $B U$ experience are based on estimates in Model 6

*Significant at $10 \%$; ** significant at $5 \%$; ${ }^{* * *}$ significant at $1 \%$.

In Models 5 and 6, neither of the interaction terms is significant. However, the coefficient and standard error for the interaction term are not particularly informative in nonlinear models. The reason is that, in count models, the effect of the interaction term (as well as the standard error) depends not only on the coefficient for the interaction but also on the coefficients for the two main effects and the values of all other variables (Ai and Norton 2003). As a result, neither sign nor significance of the interaction coefficients presented in Table 3 is indicative of the actual direction and significance of the interactions (Ai and Norton 2003, Hoetker 2007). Therefore, in Table 4 we present the attenuating effect of the interaction terms in a more appropriate way (Greene 2010). That is, we calculate the marginal effects of the performance-aspiration gap (below aspirations) at various levels of $B U$ importance and $B U$ experience. Column (1) in Table 4 shows the marginal effect of the performance-aspiration gap for the corporate level at seven different levels of the $B U$ importance variable (at its mean, mean \pm one standard deviation, mean \pm two standard deviations, and mean \pm three standard deviations). These effects are based on the estimates from Model 5, and the standard errors are calculated using the Delta method applied to the variance-covariance estimates from that model. We find that as $B U$ importance rises from three standard deviations below the mean to three standard deviations above the mean, the marginal effect of performance feedback declines consistently. This provides strong support for the attenuating 
Table 5 Social vs. Historical Aspirations

\begin{tabular}{|c|c|c|c|c|c|c|}
\hline \multirow[b]{2}{*}{ Variable } & \multicolumn{6}{|c|}{ Model } \\
\hline & 1 & 2 & 3 & 4 & 5 & 6 \\
\hline $\begin{array}{l}\text { Performance below historical } \\
\text { aspirations (business unit) }\end{array}$ & $\begin{array}{r}-2.682^{*} \\
(1.432)\end{array}$ & & $\begin{array}{r}-2.793^{*} \\
(1.454)\end{array}$ & & & \\
\hline $\begin{array}{l}\text { Performance above historical } \\
\text { aspirations (business unit) }\end{array}$ & $\begin{array}{l}2.256 \\
(1.419)\end{array}$ & & $\begin{array}{l}2.326 \\
(1.474)\end{array}$ & & & \\
\hline $\begin{array}{l}\text { Performance below social } \\
\text { aspirations (business unit) }\end{array}$ & & $\begin{array}{r}-0.151 \\
(0.941)\end{array}$ & $\begin{array}{r}-0.036 \\
(0.978)\end{array}$ & & & \\
\hline $\begin{array}{l}\text { Performance above social } \\
\text { aspirations (business unit) }\end{array}$ & & $\begin{array}{c}0.647 \\
(1.067)\end{array}$ & $\begin{array}{c}0.824 \\
(1.055)\end{array}$ & & & \\
\hline $\begin{array}{l}\text { Performance below historical } \\
\text { aspirations (corporate unit) }\end{array}$ & & & & $\begin{array}{l}3.087^{* *} \\
(1.423)\end{array}$ & & $\begin{array}{l}3.246^{* *} \\
(1.440)\end{array}$ \\
\hline $\begin{array}{l}\text { Performance above historical } \\
\text { aspirations (corporate unit) }\end{array}$ & & & & $\begin{array}{l}-2.074^{* *} \\
(0.978)\end{array}$ & & $\begin{array}{c}-1.799 \\
(1.222)\end{array}$ \\
\hline $\begin{array}{l}\text { Performance below social } \\
\text { aspirations (corporate unit) }\end{array}$ & & & & & $\begin{array}{r}-1.335 \\
(0.877)\end{array}$ & $\begin{array}{r}-1.303 \\
(0.899)\end{array}$ \\
\hline $\begin{array}{l}\text { Performance above social } \\
\text { aspirations (corporate unit) }\end{array}$ & & & & & $\begin{array}{c}0.278 \\
(0.943)\end{array}$ & $\begin{array}{c}0.564 \\
(1.081)\end{array}$ \\
\hline Age & $\begin{array}{l}-0.012^{* * *} \\
(0.004)\end{array}$ & $\begin{array}{l}-0.014^{* * *} \\
(0.004)\end{array}$ & $\begin{array}{l}-0.014^{* * *} \\
(0.004)\end{array}$ & $\begin{array}{l}-0.011^{* * *} \\
(0.004)\end{array}$ & $\begin{array}{l}-0.012^{* * *} \\
(0.004)\end{array}$ & $\begin{array}{l}-0.011^{* * *} \\
(0.004)\end{array}$ \\
\hline Number of employees & $\begin{array}{l}1.033^{* * *} \\
(0.225)\end{array}$ & $\begin{array}{l}1.009^{* * *} \\
(0.252)\end{array}$ & $\begin{array}{l}1.120^{* * *} \\
(0.266)\end{array}$ & $\begin{array}{l}1.048^{* * *} \\
(0.213)\end{array}$ & $\begin{array}{l}0.972^{* * *} \\
(0.227)\end{array}$ & $\begin{array}{l}1.095^{* * *} \\
(0.233)\end{array}$ \\
\hline Corporate sales & $\begin{array}{c}0.265 \\
(0.335)\end{array}$ & $\begin{array}{c}0.148 \\
(0.368)\end{array}$ & $\begin{array}{c}0.195 \\
(0.372)\end{array}$ & $\begin{array}{l}0.016 \\
(0.341)\end{array}$ & $\begin{array}{c}0.328 \\
(0.350)\end{array}$ & $\begin{array}{c}0.138 \\
(0.355)\end{array}$ \\
\hline Diversification & $\begin{array}{c}0.098 \\
(0.159)\end{array}$ & $\begin{array}{c}0.173 \\
(0.166)\end{array}$ & $\begin{array}{l}0.127 \\
(0.164)\end{array}$ & $\begin{array}{c}0.069 \\
(0.159)\end{array}$ & $\begin{array}{c}0.196 \\
(0.168)\end{array}$ & $\begin{array}{c}0.138 \\
(0.166)\end{array}$ \\
\hline Mobile patents & $\begin{array}{c}0.160^{*} \\
(0.095)\end{array}$ & $\begin{array}{c}0.135 \\
(0.093)\end{array}$ & $\begin{array}{c}0.182^{*} \\
(0.101)\end{array}$ & $\begin{array}{c}0.156^{*} \\
(0.086)\end{array}$ & $\begin{array}{c}0.155^{*} \\
(0.092)\end{array}$ & $\begin{array}{c}0.182^{* *} \\
(0.088)\end{array}$ \\
\hline Available slack & $\begin{array}{c}0.086 \\
(0.062)\end{array}$ & $\begin{array}{c}0.074 \\
(0.065)\end{array}$ & $\begin{array}{c}0.097 \\
(0.065)\end{array}$ & $\begin{array}{c}0.030 \\
(0.061)\end{array}$ & $\begin{array}{c}0.074 \\
(0.063)\end{array}$ & $\begin{array}{c}0.039 \\
(0.062)\end{array}$ \\
\hline Absorbed slack & $\begin{array}{c}-0.595^{* *} \\
(0.258)\end{array}$ & $\begin{array}{c}-0.457 \\
(0.280)\end{array}$ & $\begin{array}{c}-0.565^{* *} \\
(0.287)\end{array}$ & $\begin{array}{c}-0.534^{* *} \\
(0.251)\end{array}$ & $\begin{array}{c}-0.598^{* *} \\
(0.271)\end{array}$ & $\begin{array}{c}-0.643^{* *} \\
(0.269)\end{array}$ \\
\hline BU importance & $\begin{array}{c}-0.015 \\
(0.018)\end{array}$ & $\begin{array}{c}-0.015 \\
(0.019)\end{array}$ & $\begin{array}{c}-0.018 \\
(0.020)\end{array}$ & $\begin{array}{c}-0.018 \\
(0.018)\end{array}$ & $\begin{array}{c}-0.015 \\
(0.018)\end{array}$ & $\begin{array}{c}-0.020 \\
(0.018)\end{array}$ \\
\hline$B U$ experience & $\begin{array}{c}-0.192 \\
(0.347)\end{array}$ & $\begin{array}{c}-0.428 \\
(0.386)\end{array}$ & $\begin{array}{c}-0.310 \\
(0.383)\end{array}$ & $\begin{array}{c}-0.364 \\
(0.335)\end{array}$ & $\begin{array}{c}-0.416 \\
(0.354)\end{array}$ & $\begin{array}{c}-0.464 \\
(0.344)\end{array}$ \\
\hline Constant & $\begin{array}{c}5.081 \\
(3.269)\end{array}$ & $\begin{array}{c}7.077^{*} \\
(3.634)\end{array}$ & $\begin{array}{c}6.068^{*} \\
(3.605)\end{array}$ & $\begin{array}{c}8.134^{* *} \\
(3.290)\end{array}$ & $\begin{array}{c}6.163^{*} \\
(3.299)\end{array}$ & $\begin{array}{l}8.181^{* *} \\
(3.314)\end{array}$ \\
\hline Number of observations & 152 & 152 & 152 & 152 & 152 & 152 \\
\hline Number of firms & 6 & 6 & 6 & 6 & 6 & 6 \\
\hline Log-likelihood & -449.34 & -453.18 & -448.71 & -447.21 & -451.14 & -445.21 \\
\hline $\mathrm{BIC}$ & -342.58 & -334.90 & -333.79 & -346.84 & -338.98 & -340.79 \\
\hline
\end{tabular}

Note. See notes to Table 2.

*Significant at $10 \%$; ${ }^{* *}$ significant at $5 \%$; ${ }^{* * *}$ significant at $1 \%$.

effect of the business unit on the performance-aspiration gap at the corporate level. Column (2) in Table 4, which is based on the estimates from Model 6, likewise shows that as $B U$ experience increases the marginal effect of the performance-aspiration gap at the corporate level declines, which attests to its attenuating effect. More importantly, this decline in the marginal effect of performance feedback is also statistically significant (comparing and testing the ranking of coefficients in each column as the moderating variable increases over its range). We thereby obtain strong support for $\mathrm{H} 3$ and $\mathrm{H} 4$, which posit that the negative effects of corporate performance feedback are attenuated for units that are (respectively) strategically important and experienced.

\section{Post Hoc Analyses}

We performed additional post hoc analyses to provide further (albeit partial) insights into our findings. First, we report a comparison of social to historical aspirations in Table 5. Model 1 uses only business unit performance relative to historical aspirations, Model 2 replaces historical with social aspirations, and Model 3 reports performance relative to each of historical and social aspirations. Models 4-6 follow this same pattern for corporate instead of business unit performance. The last row in the table reports the Bayesian information criterion (BIC) for model selection, which penalizes the model log-likelihood for the number of parameters estimated. We find that performance relative to historical 
aspirations matters rather than relative to social aspirations, a pattern that holds at both the business unit and corporate levels. This finding also holds whether we look at the coefficient estimates and their significance or instead use the BIC to select models. BIC is the minimum in Model 1 for the business unit and in Model 4 for corporate. Therefore, this criterion again indicates that performance relative to historical aspirations matters. Our models include firm fixed effects and rely on within-firm variation to identify coefficients. A decline in corporate performance relative to historical performance within a firm is indicative of tightening resource constraints and suggests an explanation that is not purely behavioral. Real resource constraints are likely to invoke the unilateral responses (cost controls, budget cuts, reorganizations) suggested by our theory. If social aspirations mattered-so that a decline of corporate performance relative to others in the industry reduced new product introductions - then a pure behavioral explanation (i.e., one based on performance comparisons with others) would be more appropriate.

Second, our analyses so far have treated all new product introductions as being essentially similar. Yet not all new phones embody equivalent changes in terms of innovative features; in fact, most tend to be incremental improvements over earlier models. Therefore, to better understand the implications of novelty in new product introductions in this context, we identified phones in our sample that incorporate radical or architectural technology improvements (Henderson and Clark 1990) and used this as an alternative dependent variable. Toward that end, we assessed the novelty level of each phone based on its particular features. We used a conservative approach to identify truly novel changes and classified each first occurrence of a technology (e.g., WiFi, GPS, Web browser) in a phone introduced by a manufacturer as constituting a radical/architectural innovation and therefore a riskier launch-in terms of the technology and product market-than incremental products (Henderson and Clark 1990). In all, 30\% of our sample's phone introductions were classified as radical. We then performed separate analysis for phone introductions classified as incremental; the results are reported in Table 6.

In Table 6, Model 1 uses all new product introductions as the dependent variable and reproduces Model 4 from Table 2; Model 2 uses only incremental new product introductions as the dependent variable. A comparison of these two models reveals that the coefficients are similar in terms of sign, magnitude, and significance. Model 3 uses only radical new product introductions as the dependent variable. Here, we find that the coefficients for performance feedback have the right sign but are not statistically significant. Because the count of radical phone introductions shows less variation over time (ranging from 0 to 5 in the data), as a
Table 6 Incremental vs. Radical New Phone Introductions

\begin{tabular}{|c|c|c|c|c|}
\hline \multirow[b]{2}{*}{ Variable } & \multicolumn{4}{|c|}{ Model } \\
\hline & $\begin{array}{c}1 \\
\text { All } \\
\text { phones }\end{array}$ & $\begin{array}{c}2 \\
\text { Incremental } \\
\text { (count) }\end{array}$ & $\begin{array}{c}3 \\
\text { Radical } \\
\text { (count) }\end{array}$ & $\begin{array}{c}4 \\
\text { Radical } \\
\text { (dummy) }\end{array}$ \\
\hline $\begin{array}{l}\text { Performance below } \\
\text { aspirations } \\
\text { (business unit) }\end{array}$ & $\begin{array}{r}-2.305^{*} \\
(1.402)\end{array}$ & $\begin{array}{r}-2.321^{*} \\
(1.413)\end{array}$ & $\begin{array}{r}-10.974 \\
(7.049)\end{array}$ & $\begin{array}{c}-5.041 \\
(9.431)\end{array}$ \\
\hline $\begin{array}{l}\text { Performance above } \\
\text { aspirations } \\
\text { (business unit) }\end{array}$ & $\begin{array}{c}2.103 \\
(1.374)\end{array}$ & $\begin{array}{c}1.936 \\
(1.404)\end{array}$ & $\begin{array}{c}5.868 \\
(3.834)\end{array}$ & $\begin{array}{c}9.769 \\
(7.360)\end{array}$ \\
\hline $\begin{array}{l}\text { Performance below } \\
\text { aspirations } \\
\text { (corporate unit) }\end{array}$ & $\begin{array}{l}2.916^{* *} \\
(1.412)\end{array}$ & $\begin{array}{l}2.897^{* *} \\
(1.425)\end{array}$ & $\begin{array}{c}9.659 \\
(6.672)\end{array}$ & $\begin{array}{r}19.975^{*} \\
(11.741)\end{array}$ \\
\hline $\begin{array}{l}\text { Performance above } \\
\text { aspirations } \\
\text { (corporate unit) }\end{array}$ & $\begin{array}{c}-1.922^{* *} \\
(0.973)\end{array}$ & $\begin{array}{c}-1.955^{* *} \\
(0.978)\end{array}$ & $\begin{array}{c}0.883 \\
(6.125)\end{array}$ & $\begin{array}{r}-4.275 \\
(9.478)\end{array}$ \\
\hline Age & $\begin{array}{c}-0.010^{* * * *} \\
(0.004)\end{array}$ & $\begin{array}{l}-0.011^{* * *} \\
(0.004)\end{array}$ & $\begin{array}{c}0.018 \\
(0.016)\end{array}$ & $\begin{array}{c}-0.011 \\
(0.021)\end{array}$ \\
\hline $\begin{array}{l}\text { Number of } \\
\text { employees }\end{array}$ & $\begin{array}{l}1.120^{* * *} \\
(0.223)\end{array}$ & $\begin{array}{l}1.167^{* * *} \\
(0.225)\end{array}$ & $\begin{array}{c}-2.633 \\
(1.897)\end{array}$ & $\begin{array}{c}-3.795^{* *} \\
(1.828)\end{array}$ \\
\hline Corporate sales & $\begin{array}{c}0.084 \\
(0.343)\end{array}$ & $\begin{array}{c}0.068 \\
(0.347)\end{array}$ & $\begin{array}{c}1.132 \\
(1.454)\end{array}$ & $\begin{array}{l}1.292 \\
(2.124)\end{array}$ \\
\hline Diversification & $\begin{array}{c}0.028 \\
(0.158)\end{array}$ & $\begin{array}{c}0.047 \\
(0.159)\end{array}$ & $\begin{array}{c}-1.060 \\
(0.934)\end{array}$ & $\begin{array}{c}0.065 \\
(1.391)\end{array}$ \\
\hline Mobile patents & $\begin{array}{l}0.191^{* *} \\
(0.092)\end{array}$ & $\begin{array}{l}0.210^{* *} \\
(0.093)\end{array}$ & $\begin{array}{c}-0.474 \\
(0.346)\end{array}$ & $\begin{array}{c}0.218 \\
(0.546)\end{array}$ \\
\hline Available slack & $\begin{array}{c}0.049 \\
(0.062)\end{array}$ & $\begin{array}{c}0.043 \\
(0.063)\end{array}$ & $\begin{array}{c}0.278 \\
(0.238)\end{array}$ & $\begin{array}{c}0.105 \\
(0.483)\end{array}$ \\
\hline Absorbed slack & $\begin{array}{c}-0.633^{* *} \\
(0.256)\end{array}$ & $\begin{array}{c}-0.618^{* *} \\
(0.257)\end{array}$ & $\begin{array}{c}-0.744 \\
(1.274)\end{array}$ & $\begin{array}{c}0.835 \\
(1.926)\end{array}$ \\
\hline BU importance & $\begin{array}{c}-0.020 \\
(0.018)\end{array}$ & $\begin{array}{c}-0.019 \\
(0.018)\end{array}$ & $\begin{array}{c}-0.037 \\
(0.059)\end{array}$ & $\begin{array}{c}-0.024 \\
(0.132)\end{array}$ \\
\hline$B U$ experience & $\begin{array}{c}-0.221 \\
(0.339)\end{array}$ & $\begin{array}{c}-0.353 \\
(0.349)\end{array}$ & $\begin{array}{l}2.790^{* *} \\
(1.106)\end{array}$ & $\begin{array}{c}-0.337 \\
(0.752)\end{array}$ \\
\hline Constant & $\begin{array}{l}6.833^{* *} \\
(3.318)\end{array}$ & $\begin{array}{l}7.655^{* *} \\
(3.392)\end{array}$ & $\begin{array}{l}-37.929 \\
(3,392.73)\end{array}$ & \\
\hline $\begin{array}{l}\text { Number of } \\
\text { observations }\end{array}$ & 152 & 152 & 152 & 152 \\
\hline $\begin{array}{l}\text { Number of } \\
\text { firms }\end{array}$ & 6 & 6 & 6 & 6 \\
\hline $\begin{array}{l}\text { Pseudo } \\
\quad \text { log-likelihood }\end{array}$ & -443.88 & -441.37 & -82.75 & -57.49 \\
\hline
\end{tabular}

Notes. For the dependent variable, Model 1 uses all phones introduced, Model 2 uses only phone introductions classified as incremental improvements, and Model 3 uses only phone introductions classified as radical improvements. Models 1-3 use a Poisson specification; Model 4 uses a conditional fixed-effects logit model. Standard errors are given in parentheses; the standard errors in Models 1-3 are corrected for overdispersion by multiplying them by the square root of the ratio of the goodnessof-fit chi-square value to the number of degrees of freedom. All columns include time (quarter-year) and firm fixed effects. The performance-aspiration gap variables are lagged by four quarters for the corporate unit and by one quarter for the business unit. *Significant at $10 \%$; ** significant at $5 \% ;{ }^{* * *}$ significant at $1 \%$.

final check, we created a dummy variable set equal to 1 only if a firm introduced a radical phone in a particular quarter-year. We then used Chamberlin's conditional fixed-effects logit model to evaluate the extent to which 
performance-aspiration gaps at the business unit and corporate levels affect the likelihood of a radical new phone introduction; these estimates are reported in Table 6 as Model 4. Once again, the coefficients for our variables of interest remain insignificant. Overall, these results suggest that our hypothesized effects apply to incremental but not to radical new product introductions. As noted previously, a business unit that faces declining performance will focus on more incremental product launches, which draw on existing competencies, to the exclusion of radical product launches, which entail the commitment of more resources and are often outside the unit's domain of experience. ${ }^{12}$ Interestingly, if we drop the firm dummies, then corporate performance below aspirations becomes significant. Hence there is at least weak evidence that performance deterioration at the corporate level leads also to fewer radical product introductions.

\section{Discussion}

This study's main objective is to investigate the effects of corporate and business unit performance feedback on business unit adaptation in multidivisional firms. Specifically, we hypothesize and confirm diverging effects of corporate and business unit responses to performance below aspirations on new product introductions. The difference stems from each organizational unit's repertoire of responses to address poor performance. Business units in such cases respond with actions aimed at streamlining operations and increasing revenue in core product market; these actions naturally accelerate product commercialization. In contrast, corporate managers focus on external capital market pressures for short-term firm-level profitability and respond to poor performance accordingly. In such cases the corporate office may rely on unilateral actions as budget cuts and structural changes to the corporation. Yet the former may constrain business unit activities and the latter may be disruptive at a time when business unit managers require focus and resources. Furthermore, business units may anticipate major budget decrements and consequently limit product changes. Thus the typical corporate responses clearly constrain the business unit's capacity to introduce new products.

Our post hoc analysis enriches the initial findings. We discover that business unit responses to performance below aspirations affect incremental new product introductions but not radical new product introductions. The reason may be that incremental phones can be rapidly commercialized and are a natural outcome of business unit response repertoires targeted at accelerating downstream activities. However, radical technologies and features are more directly affected by the firm's resource constraints. At the corporate level, the responses of cost cutting and reducing slack are likely to affect both upstream research and development (R\&D) and downstream business unit functions. This may explain our finding evidence for corporate feedback effects on both incremental and radical new product introductions. We also find that historical aspirations matter but social aspirations do not, which supports the claim that resource constraints-not social comparisonsdrive corporate behavior and thus impede business unit adaptation.

We also find that the adverse effect of poor corporate performance on new product introductions is attenuated for strategically significant business units. In other words, the implications of problemistic search for business units that are strategically significant tend to converge with that of the corporate office. By incorporating the suggestions of strategically significant business units, the corporate office may locate tactical solutions more readily and, in general, exploit the advantage of greater operational expertise and knowledge. Also, the business unit may be granted more influence in corporate decision making and thus be better able to fend off cuts in resources or unwarranted organizational changes, thereby limiting the adverse effects of poor corporate performance. Although our study does not provide insights into the exact nature of the exchange between the corporate office and the business units, extant research suggests that it may occur through decision-making channels (Ocasio and Joseph 2005, Joseph and Ocasio 2012), executive mobility (Boeker 1997), or greater political clout of business unit managers with the corporate office (Bouquet and Birkinshaw 2008). These factors merit greater exploration.

Our study offers two main contributions. First, it helps explain how vertically differentiated attention to multiple performance goals within the multidivisional firm influences the relationship between performance feedback and adaptive behavior. Studies that accommodate multiple aspiration levels are in short supply, and we know little of how managers allocate attention in the face of multiple performance goals. Existing studies suggest that, to deal with the cognitive overload or political discord engendered by multiple goals, units may need to create a subgoal focus or attend to goals sequentially. The horizontal separation of goals (i.e., from other divisional goals) has two principal benefits: (i) it helps the firm manage interdependencies that would otherwise limit its pursuit of multiple performance goals, and (ii) it prevents "performance freeze," which would limit decision making that could enhance organizational performance across the full array of goals (Ethiraj and Levinthal 2009). Researchers have shown that functionally discrete goals increase responsiveness to performance feedback (Audia and Sorenson 2001, Baum et al. 2005), but corporate structure has not—until now-been a consideration in this area of research. 
We propose that, as regards attention paid to goals, vertical differentiation yields outcomes unlike those predicted under horizontal differentiation. Thus, our study uncovers a unique consequence of the corporate structure. In particular, the very nature of performance feedback and problem solving differs as a function of the organizational context, so the level's response and effect on unit behavioral outcomes differ likewise. That is, the nature of problemistic search depends on the level at which goals are attended to and the level at which responses to performance feedback are enacted. Although Williamson (1975) and others have noted the virtues of separating strategic and operational decision making, they are not concerned with adaptive change. We remark that, moreover, the foundational M-form work did not consider the interplay between structural drivers and managerial attitudes toward loss. Our results therefore indicate that the organizational hierarchy and division of labor makes a difference in performance feedback theory and should be incorporated more directly into future studies of learning.

Second, our study augments the literature on the role of corporate headquarters in the adaptation of business units (Galunic and Eisenhardt 2001, Helfat and Eisenhardt 2004, Ambos and Birkinshaw 2010, Joseph and Ocasio 2012). Corporate activities figure largely in attempts to address changes in firm performance and the environment, and it consists of a continuous process of adjusting capabilities (Galunic and Eisnhardt 2001), managing talent (Karim and Williams 2012), and making strategic choices (Chakravarthy 1982). For the corporate office, responses to poor performance include solutions that have significance for the maintenance of the entire organization-even at the expense of a single unit. The implication that follows from our theory is that corporate problem-solving efforts may encumber activities at the business unit level when doing so is necessary to ensure the organization's survival. Solutions to performance problems often reside at the lowest levels of an organization (Greve 2003b, p. 148), but corporate preoccupation with the firm's overall performance feedback may impede the realization of those lower-level solutions. Only when the business unit can influence the broader realignment of priorities and investments within the firm (Bouquet and Birkinshaw 2008, Ambos and Birkinshaw 2010) is there abatement in the adverse effects of the corporate response to poor performance.

Our research has limitations. First, conclusions drawn from studying the mobile device industry should be extrapolated with caution to firms in other industries. The global mobile device industry has only a few large players, and industries with different competitive dynamics might well yield different results for when corporate versus business unit effects dominate. Second, we focus on the corporate response to performance feedback and its impact on a single business unit within a multidivisional firm. Top management actually focuses on a host of goals, and the consequences of attention to multiple simultaneous goals at both the corporate and business unit levels should be considered in research on this subject. Future studies may also seek to understand the effects of corporate response repertoires on product output from multiple business units in the firm's portfolio, a topic whose exploration was not feasible given the data limitations of this study. Third, even though our analysis seeks explicitly to understand the effects of corporate performance feedback on business unit activities, we do not directly observe the repertoire of corporate responses. However, the literature suggests that these levers are diverse in nature and include internal changes to division charters (Galunic and Eisenhardt 1996), shifts in how resources are allocated (Noda and Bower 1996), and changes to how costs are allocated (Burgelman 2002). Our anecdotal evidence is consistent with these studies and suggests that the identified responses often occur in combination and involve both major and minor adjustments. Capturing these finegrained phenomena is a challenge worthy of future research. Our study provides a complement to previous case studies, a basis for future work, and a quantitative longitudinal assessment of corporate responses to a single unit's poor performance.

Finally, our analysis can provide only limited insight into how single-business firms would behave. If we extend the logic of the preceding analysis, then our findings seem to suggest that, as strategically significant business units become the dominant business of the firm (or the only business in the firm), overall responsiveness to feedback should more closely resemble that of the business unit than of the corporation. Yet there may also be limits to the favorable effect of a business unit voice in corporate decision making. The top management of public firms with a dominant business are likely to face investor pressures and behave myopically and, in cases of poor performance, to limit long-term investments that could eventually facilitate adaptation. For example, Audia and Greve (2006) find that firmlevel attainment discrepancies (analogous to our corporate performance-aspiration gaps) among large Japanese shipbuilders reduce investment in physical assets and employees. In a study of acquisition propensity in a large sample of manufacturing firms, Iyer and Miller (2008) find evidence that poor firm-level performance results in fewer acquisitions. Although we cannot definitively identify the point at which business unit and corporate behaviors converge, we do suggest some levers that may drive their common behavior under such conditions-in particular, the role played by corporate attention in the adaptation of business units.

\section{Conclusion}

Given the paradox faced by headquarters-namely, that its actions to improve corporate performance may 
impede the business unit activities most likely to effect that improvement-it is critical for performance that managers strike a workable balance. In particular, structural differentiation must be balanced by greater corporate attention to the divisional effects of tightening resources and to the input that business units can provide on the firm's overall agenda. Corporate effects on firm performance are well documented (McGahan and Porter 1999), as is the importance of business unit initiatives in strategic adaptation. Less clear are the effects of integrating corporate and business units, especially on adaptive behavior. This study is one step in that direction. Though contrary to the foundational literature, which warns against such integration (Williamson 1975), our results are consistent with those of scholars who document a more active role for business units in strategic decision making (Bouquet and Birkinshaw 2008, Joseph and Ocasio 2012). In fact, increased integration of the issues and initiatives to which corporate and business units both attend may result in better outcomes to the extent that the resource and information requirements of corporate and divisional managers can be better balanced without affecting either group's functions. These integrative linkages are well suited to aligning perspectives on problems, opportunities, and actions in support of adaptive change.

\section{Acknowledgments}

The authors thank Phil Anderson, Rich Burton, Sendil Ethiraj, Kira Fabrizio, Henrich Greve, Theresa Lant, Dan Levinthal, Will Mitchell, William Ocasio, Lori Rosenkopf, and Sim Sitkin as well as participants at the Wharton Technology Conference, London Business School Strategy Conference, INSEAD Entrepreneurship Research Workshop, and Academy of Management symposium for their helpful comments on previous versions of the paper. They also thank senior editor Mary Benner and two anonymous reviewers for their insightful suggestions. Both authors contributed equally to this work.

\section{Endnotes}

${ }^{1}$ We also tried using longer lags for the business unit performance-aspiration gap measure, which yielded qualitatively similar results.

${ }^{2} \mathrm{We}$ also experimented with $B U$ size (measured by business unit sales over corporate sales) as another indicator of strategic significance. Using this variable did not yield significant results, and including it as an additional control likewise left our findings unaffected.

${ }^{3} \mathrm{~A}$ control variable for $\mathrm{R} \& \mathrm{D}$ spending was created, but it proved to be always nonsignificant (even in the baseline model) and so was not included in the final models.

${ }^{4} \mathrm{We}$ also evaluated the robustness of our results to the presence of cyclicality in the data. First, we controlled for the growth in sales of mobile phones lagged by 1-4 quarters. If cyclicality were present, then we would expect a negative coefficient for sales growth-as sales growth tapers off, it spurs the introduction of new phones. We find that sales growth lagged four quarters is negative and significant. However, we also find our results are stronger in terms of both statistical significance and the magnitude of the hypothesized coefficients. Second, we used the dependent variable lagged by 1-4 quarters as an additional regressor. If new product introductions follow a cyclical pattern, then some (if not all) of these lags should have a significant effect on concurrent phone introductions. In the fully specified models, none of the lagged dependent variables significantly influences new product introductions, even as our hypothesized effects remain supported.

${ }^{5}$ We calculated variance inflation factors (VIFs) for each independent variable. Each factor (excepting the VIF for corporate sales) is less than 10 , so multicollinearity is not a major problem for our coefficients of interest.

${ }^{6}$ Wooldridge (1999) shows that parameterization based on a negative binomial distribution is not robust. In particular, specifying a distribution for the conditional mean and the overdispersion parameter-and then maximizing the likelihood with respect to all parameters-generally produces inconsistent estimates for the conditional means.

${ }^{7}$ Please note that overdispersion does not lead to inconsistent estimates of the coefficients. It simply yields lower standard errors than what they should be. On the other hand, omitting relevant fixed effects in a negative binomial specification does lead to inconsistent estimates, which is a far more serious problem. Ahuja (2000), Azoulay et al. (2010), and Singh and Agrawal (2011) all underscore the appropriateness of a fixed-effects Poisson estimator.

${ }^{8}$ Our results are robust to the use of forward patent citations as an alternative measure of capabilities.

${ }^{9}$ Performance deteriorations below aspirations at the corporate unit may be perceived as a threat to its survival, which in turn might influence its responses (March and Shapira 1992). Therefore, as a robustness check, we added a control for risk of firm bankruptcy using the Altman Z-measure (Iyer and Miller 2008). Our results are robust to the inclusion of this additional control.

${ }^{10}$ The coefficients in Table 2 can themselves be interpreted as semielasticities.

${ }^{11} \mathrm{We}$ also interacted the performance feedback variables with corporate sales, diversification, and $B U$ size. No consistent patterns were evident for these interaction effects.

${ }^{12} \mathrm{We}$ reran our analysis using longer lags of the business unit performance-aspiration gap on the likelihood of radical product introductions. Even at the longer lags, we failed to find any significant effects.

\section{References}

Abernathy WJ, Utterback J (1978) Patterns of industrial innovation. Technology Rev. 80(7):40-47.

Ahuja G (2000) Collaboration networks, structural holes, and innovation: A longitudinal study. Admin. Sci. Quart. 45(3):425-455.

Ai C, Norton EC (2003) Interaction terms in logit and probit models. Econom. Lett. 80(1):123-129.

Allison P, Waterman R (2002) Fixed-effects negative binomial regression models. Sociol. Methodol. 32(1):247-265.

Ambos T, Birkinshaw J (2010) Headquarters' attention and its effects on subsidiary performance. Management Internat. Rev. 50(4):449-469.

Audia PG, Greve HR (2006) Less likely to fail: Low performance, firm size, and factory expansion in the shipbuilding industry. Management Sci. 52(1):83-94. 
Audia PG, Brion S (2007) Reluctant to change: Self-enhancing responses to diverging performance measures. Organ. Behav. Human Decision Processes 102(2):255-269.

Audia PG, Sorenson O (2001) Aspirations, performance and organizational change: A multilevel analysis. Working paper, Dartmouth University, Hanover, NH.

Audia PG, Locke EA, Smith KG (2000) The paradox of success: An archival and a laboratory study of strategic persistence following radical environmental change. Acad. Management J. 43(5):837-853.

Azoulay P, Zivin J, Wang J (2010) Superstar extinction. Quart. J. Econom. 125(2):549-589.

Baum JAC, Rowley TJ, Shipilov AV, Chuang Y-T (2005) Dancing with strangers: Aspiration performance and the search for underwriting syndicate partners. Admin. Sci. Quart. 50(4):536-575.

Benner MJ (2010) Securities analysts and incumbent response to radical technological change: Evidence from digital photography and internet telephony. Organ. Sci. 21(1):42-62.

Birkinshaw JM, Hood N, Johnson S (1998) Building firm-specific advantages in multinational corporations: The role of subsidiary initiative. Strategic Management J. 19(3):221-242.

Boeker W (1997) Strategic change: The influence of managerial characteristics and organizational growth. Acad. Management $J$. 40(1):152-170.

Bouquet C, Birkinshaw J (2008) Managing power in the multinational corporation: How low-power actors gain influence. J. Management 34(3):477-508.

Bower JL (1970) Managing the Resource Allocation Process (Harvard University Press, Cambridge, MA).

Bromily P (1991) Testing a causal model of corporate risk taking and performance. Acad. Management J. 34(1):37-59.

Brown SL, Eisenhardt KM (1995) Product development: Past research, present findings and future directions. Acad. Management J. 20(2):343-378.

Burgelman RA (1991) Intraorganizational ecology of strategy making and organizational adaptation: Theory and field research. Organ. Sci. 2(3):239-262.

Burgelman RA (2002) Strategy as vector and the inertia of coevolutionary lock-in. Admin. Sci. Quart. 47(2):325-357.

Burgelman RA, Grove AS (1996) Strategic dissonance. Calif. Management Rev. 38(2):8-28.

Bushee BJ (1998) The influence of institutional investors on myopic R\&D investment behavior. Accounting Rev. 73(3):305-333.

Cameron A, Trivedi R (2005) Microeconometrics: Methods and Applications (Cambridge University Press, Cambridge, UK).

Chakravarthy BS (1982) Adaptation: A promising metaphor for strategic management. Acad. Management Rev. 7(1):35-44.

Chandler AD (1962) Strategy and Structure: Chapters in the History of American Enterprise (MIT Press, Cambridge, MA).

Clarke KA (2003) Nonparametric model discrimination in international relations. J. Conflict Resolution 47(1):72-93.

Cyert RM, March JG (1963) A Behavioral Theory of the Firm (Prentice-Hall, Englewood Cliffs, NJ).

Daft RL, Weick KE (1984) Toward a model of organizations as interpretive systems. Acad. Management Rev. 9(2):284-295.

Dougherty D (1992) A practice-centered model of organizational renewal through product innovation. Strategic Management $J$. 13(S1):77-92.
Ethiraj SK, Levinthal D (2004) Bounded rationality and the search for organizational architecture: An evolutionary perspective on the design of organizations and their evolvability. Admin. Sci. Quart. 49(3):404-437.

Ethiraj SK, Levinthal D (2009) Hoping for $A$ to $Z$ while rewarding only A: Complex organizations and multiple goals. Organ. Sci. 20(1):4-21.

Gaba V, Bhattacharya S (2012) Aspirations, innovation, and corporate venture capital: A behavioral perspective. Strategic Entrepreneurship J. 6(2):178-199.

Galunic DC, Eisenhardt KM (1996) The evolution of intracorporate domains: Divisional charter losses in high-technology, multidivisional corporations. Organ. Sci. 7(3):255-282.

Galunic DC, Eisenhardt KM (2001) Architectural innovation and modular corporate forms. Acad. Management J. 44(6):1229-1249.

Greene WH (2003) Econometric Analysis (Prentice-Hall, Upper Saddle River, NJ).

Greene WH (2010) Testing hypotheses about interaction terms in nonlinear models. Econom. Lett. 107(2):291-296.

Greve HR (1998) Performance aspirations, and risky organizational change. Admin. Sci. Quart. 43:58-86.

Greve HR (2003a) A behavioral theory of R\&D expenditures and innovation: Evidence from shipbuilding. Acad. Management $J$. 46(6):685-702.

Greve HR (2003b) Organizational Learning from Performance Feedback: A Behavioral Perspective on Innovation and Change (Cambridge University Press, Cambridge, UK).

Greve HR (2007) Exploration and exploitation in product innovation. Indust. Corporate Change 16(5):945-975.

Hambrick DC, D'Aveni RA (1988) Large corporate failures as downward spirals. Admin. Sci. Quart. 33(1):1-23.

Hambrick DC, Schecter SM (1983) Turnaround strategies for mature industrial-product business units. Acad. Management $J$. 26(2):231-248.

Hardin JW, Hilbe JM (2007) Generalized Linear Models and Extensions (Stata Press, College Station, TX).

Hausman J, Hall B, Griliches Z (1984) Econometric models for count data with an application to the patents-R\&D relationship. Econometrica 52(4):909-938.

Haveman HA (1992) Between a rock and a hard place: Organizational change and performance under conditions of fundamental environmental transformation. Admin. Sci. Quart. 37(1):48-75.

Helfat CE, Eisenhardt KM (2004) Inter-temporal economies of scope, organizational modularity, and the dynamics of diversification. Strategic Management J. 25(13):1217-1232.

Henderson RM, Clark KB (1990) Architectural innovation: The reconfiguration of existing product technologies and the failure of established firms. Admin. Sci. Quart. 35(1):9-30.

Hickson DJ, Hinings CR, Lee CA, Schneck RE, Pennings JM (1971) A strategic contingencies' theory of intraorganizational power. Admin. Sci. Quart. 16(2):216-229.

Hill CWL, Hoskisson RE (1987) Strategy and structure in the multiproduct firm. Acad. Management Rev. 12(2):331-341.

Hoetker G (2007) The use of logit and probit models in strategic management research: Critical issues. Strategic Management J. 28(4):331-343.

Hoskisson RE, Hitt MA, Hill CWL (1993) Managerial incentives and investment in R\&D in large multiproduct firms. Organ. Sci. $4(2): 325-341$ 
Iyer DN, Miller K (2008) Performance feedback, slack, and the timing of acquisitions. Acad. Management J. 51(4):808-822.

Joseph J, Ocasio W (2012) Architecture, attention, and adaptation in the multibusiness firm: General Electric from 1951 to 2001. Strategic Management J. 33(6):633-660.

Kaplan SN, Minton B (2006) How has CEO turnover changed? Increasingly performance sensitive boards and increasingly uneasy CEOs. NBER Working Paper 12465, National Bureau of Economic Research, Cambridge, MA.

Karim S, Williams C (2012) Structural knowledge: How executive experience with structural composition affects intrafirm mobility and unit reconfiguration. Strategic Management $J$. 33(6):681-709.

Katila R, Ahuja G (2002) Something old, something new: A longitudinal study of search behavior and new product introduction. Acad. Management J. 45(8):1183-1194.

Krubasik EG (1988) Customize your product development. Harvard Bus. Rev. 66(6):46-52.

Lant TK, Milliken F, Batra B (1992) The role of managerial learning and interpretation in strategic persistence and reorientation: An empirical exploration. Strategic Management J. 13(8):585-608.

March JG, Shapira Z (1992) Variable risk preferences and the focus of attention. Psych. Rev. 99(1):172-183.

March JG, Simon HA (1958) Organizations (John Wiley \& Sons, New York).

Martin X, Mitchell W (1998) The influence of local search and performance heuristics on new design introduction in a new product market. Res. Policy 26(7-8):753-771.

McGahan AM, Porter ME (1999) The persistence of shocks to profitability. Rev. Econom. Statist. 81(1):143-152.

Miller D, Chen M-J (1994) Sources and consequences of competitive inertia. Admin. Sci. Quart. 39(1):1-23.

Miller D, Chen M-J (1996) The simplicity of competitive repertoires: An empirical analysis. Strategic Management J. 17(6):419-439.

Miller D, Friesen PH (1984) Organizations: A Quantum View (Prentice-Hall, Englewood Cliffs, NJ).

Miller KD, Chen W-R (2004) Variable organizational risk preferences: Tests of the March-Shapira model. Acad. Management J. 47(1):105-115.

Mitchell W (1994) The dynamics of evolving markets: The effect of business sales and age on dissolutions and divestitures. Admin. Sci. Quart. 39(4):575-602.

Noda T, Bower JL (1996) Strategy making as iterated processes of resource allocation. Strategic Management J. 17(S1):159-192.

Ocasio W (1995) The enactment of economic adversity: A reconciliation of theories of failure-induced change and threat-rigidity. Cummings LL, Staw BM, eds. Research in Organizational Behavior, Vol. 17 (JAI Press, Greenwich, CT), 287-331.

Ocasio W (1997) Towards an attention-based view of the firm. Strategic Management J. 18(S1):187-206.

Ocasio W, Joseph J (2005) An attention-based view of strategy formulation: Linking micro- and macroperspectives in strategy processes. Szulanski G, Porac J, Doz Y, eds. Strategy Process (Advances in Strategic Management, Vol. 22) (Elsevier, Oxford, UK), 39-61.

Palepu K (1985) Diversification strategy, profit performance and the entropy measure. Strategic Management J. 6(3):239-255.
Park KM (2007) Antecedents of convergence and divergence in strategic positioning: The effects of performance and aspiration on the direction of strategic change. Organ. Sci. 18(3):386-402.

Pfeffer J (1992) Managing with Power: Politics and Influence in Organizations (Harvard University Press, Boston).

Porac JF, Thomas H (1990) Taxonomic mental models in competitor definition. Acad. Management Rev. 15(2):224-240.

Porter ME (1992) Capital disadvantage: America's failing capital investment system. Harvard Bus. Rev. 70(SeptemberOctober):65-83.

Schneider SL (1992) Framing and conflict: Aspiration level contingency, the status quo, and current theories of risky choice. J. Experiment. Psych.: Learn., Memory, Cognition 18(5):1040-1057.

Simon HA (1947) Administrative Behavior (Free Press, New York).

Simon HA (1957) Models of Man (John Wiley \& Sons, New York).

Simon HA (1962) The architecture of complexity. Proc. Amer. Philos. Soc. 106(6):467-482.

Singh J, Agrawal A (2011) Recruiting for ideas: How firms exploit the prior inventions of new hires. Management Sci. 57(1):129-150.

Sorenson JB, Stuart TE (2000) Aging, obsolescence and organizational innovation. Admin. Sci. Quart. 45(1):81-112.

Stein JC (1989) Efficient capital markets, inefficient firms: A model of myopic corporate behavior. Quart. J. Econom. 104(4):655-669.

Tripsas M, Gavetti G (2000) Capabilities, cognition, and inertia: Evidence from digital imaging. Strategic Management J. 21(1011):1147-1161.

Vissa B, Greve HR, Chen W-R (2010) Business group affiliation and firm search behavior in India: Responsiveness and focus of attention. Organ. Sci. 21(3):696-712.

Wiersema MF, Zhang Y (2011) CEO dismissal: The role of investment analysts. Strategic Management J. 32(11):1161-1182.

Williamson OE (1970) Corporate Control and Business Behavior (Prentice-Hall, Englewood Cliffs, NJ).

Williamson OE (1975) Markets and Hierarchies: Analysis and Antitrust Implications (Free Press, New York).

Williamson OE (1985) The Economic Institutions of Capitalism (Free Press, New York).

Wooldridge JM (1999) Distribution-free estimation of some nonlinear panel data models. J. Econometrics 90(1):77-97.

Vibha Gaba is an associate professor of organizational behavior and a member of the faculty at INSEAD. She received her Ph.D. from the Lundquist College of Business, University of Oregon. Her research interests include innovation diffusion and strategic adaptation in response to uncertain environments and performance shortfalls with particular emphasis on the role of different learning mechanisms.

John Joseph is an assistant professor of strategy and a member of the graduate faculty at the Fuqua School of Business, Duke University. He received his Ph.D. from Northwestern University. His research interests include strategy formulation, innovation, and decision making with particular emphasis on the role of organizational structure, goals, and attention. 